\title{
Source apportionment of particles at Station Nord, North East Greenland during 2008-2010 using COPREM and PMF analysis
}

\author{
Q. T. Nguyen ${ }^{1,2}$, H. Skov ${ }^{1,3,4}$, L. L. Sørensen ${ }^{1,4}$, B. J. Jensen ${ }^{1}$, A. G. Grube ${ }^{1}$, A. Massling ${ }^{1}$, M. Glasius ${ }^{2}$, and \\ J. K. Nøjgaard ${ }^{1}$ \\ ${ }^{1}$ Department of Environmental Science, Aarhus University, 4000 Roskilde, Denmark \\ ${ }^{2}$ Department of Chemistry, Aarhus University, 8000 Aarhus, Denmark \\ ${ }^{3}$ Adjunct Professor University of Southern Denmark, Institute of Chemical Engineering and Biotechnology and \\ Environmental Technology, Niels Bohrs Allé 1, 5230 Odense M, Denmark \\ ${ }^{4}$ Arctic Research Centre, Aarhus University, 8000 Aarhus, Denmark
}

Correspondence to: Q. T. Nguyen (quynh@ @ chem.au.dk)

Received: 14 July 2012 - Published in Atmos. Chem. Phys. Discuss.: 17 September 2012

Revised: 17 December 2012 - Accepted: 17 December 2012 - Published: 4 January 2013

\begin{abstract}
In order to develop strategies for controlling and reducing Arctic air pollution, there is a need to understand the basic mechanisms for determining the fate of air pollution in the Arctic. Sources of atmospheric particles at Station Nord $\left(81^{\circ} 36^{\prime} \mathrm{N}, 16^{\circ} 40^{\prime} \mathrm{W}\right)$ in North East Greenland were evaluated for a two-year period from March 2008 to February 2010. Source apportionment using Positive Matrix Factorization (PMF) and COnstrained Physical REceptor Model (COPREM) was based on measurements of black carbon, elements (Al, Si, S, K, Ca, Ti, V, Cr, Mn, Fe, Ni, Cu, Zn, Ga, $\mathrm{As}, \mathrm{Se}, \mathrm{Br}, \mathrm{Rb}, \mathrm{Sr}, \mathrm{Zr}, \mathrm{Pb})$ and inorganic ions $\left(\mathrm{SO}_{2}, \mathrm{SO}_{4}^{2-}\right.$, $\mathrm{Na}^{+}, \mathrm{NH}_{4}^{+}, \mathrm{NO}_{3}^{-}, \mathrm{Cl}^{-}$). In general, source apportionment results by PMF and COPREM showed good agreement. Five sources adequately explained the measurements, which included a Marine and a Soil source of natural origin and three additional anthropogenic sources, which were all influenced by metal industries. One anthropogenic source was dominated by $\mathrm{Zn}$ of which air mass back trajectories using the Hybrid Single Particle Lagrangian Integrated Trajectory (HYSPLIT) model suggested a Canadian Arctic origin, despite certain influences from Southern and Eastern origins. Another anthropogenic source was characterised by high concentrations of $\mathrm{Pb}$ and $\mathrm{As}$, which has been historically referred to as a Combustion source at Station Nord. The impacts of largescale industry in Siberia, Russia were evident through high $\mathrm{Cu}$ concentrations in both the Combustion source and an additional $\mathrm{Cu} / \mathrm{Ni}$ source.
\end{abstract}

$\mathrm{Br}$ correlated well with the anthropogenic species $\mathrm{S}$ and $\mathrm{Pb}$ though the elements are unlikely to have a common origin. More likely, sulphuric acid aerosols serve as transport containers for $\mathrm{Br}$ species of marine origin. Of particular relevance to climate, sources of black carbon were identified to be mainly anthropogenic and most probably of Siberian origin $(80-98 \%)$.

\section{Introduction}

The global temperature increase has been primarily wellattributed to anthropogenic emissions of carbon dioxide. However, the temperature in the Arctic has increased at a rate twice as high as the rest of the world (IPCC, 2007), which has been partly explained by the surface forcing and surface temperature response of short-lived pollutants including methane, tropospheric ozone and black carbon (Quinn et al., 2008; ACIA, 2004). Model calculations suggest that black carbon (BC) contributes significantly to Arctic warming through direct absorption of incoming light and indirectly by reducing the albedo of especially snow and ice-covered surfaces (Hansen and Nazarenko, 2004; Flanner et al., 2007, 2009).

Investigations over the past decades have shown that a considerable part of Greenlandic, Norwegian, Russian, Northern USA and Canadian Arctic troposphere is significantly influenced by atmospheric pollution of distant latitude origin 
(Heidam et al., 1999, 2004; Flyger et al., 1980; Barrie et al., 1981; Pacyna et al., 1984; Bourgeois and Bey, 2011). The phenomenon which is known as Arctic haze is widespread throughout the Arctic during wintertime. Most notable identified sources include the industrial and other anthropogenic activities in the Eurasian region (particularly northern Russia and central Europe) and North America (Heidam et al., 1999; Shindell et al., 2008; Bourgeois and Bey, 2011). Arctic haze aerosols contain a mixture of sulphate $\left(\mathrm{SO}_{4}^{2-}\right)$, organic matter (OM), $\mathrm{BC}$ and dust, nitrogen compounds, heavy metals and other elements (e.g. Li and Barrie, 1993; Quinn et al., 2002). The Arctic haze phenomenon results in a typical annual variation with elevated concentrations of such elements during Arctic winter while the deposition frequency during this time of year is low which limits the removal of Arctic haze through deposition (Quinn et al., 2007; Heidam et al., 1999, 2004; Barrie et al., 1981). Arctic haze may also generally add to the warming trend of the Arctic through its potential to absorb thermal infrared radiation (Garrett and Zhao, 2006) and also incoming solar radiation when present on top of snow and ice-covered surfaces.

During the Arctic haze phenomenon, the air in the Arctic lower troposphere is partially isolated from other layers of the atmosphere by the so-called "Arctic Front" barrier, resulting in low potential temperatures at the ground surface (Klonecki et al., 2003; Stohl, 2006). A transported polluted air mass originating from outside the Arctic must have a similar low potential temperature (Barrie, 1986; Carlson, 1981; Iversen, 1984; AMAP, 2011; Stohl, 2006), which thus emphasizes relatively colder regions such as Northern Eurasia as a major mid-latitude pollution source region in comparison to other regions further south where the air masses are too warm to reach the Arctic lower troposphere (Barrie, 1986; Eckhardt et al., 2003; Heidam et al., 2004; Klonecki et al., 2003).

Emissions from sources within the Arctic must also be considered to obtain a complete picture of the particle burden in this region. The non-ferrous metal smelters on the Kola Peninsula (Nikel, Monchegorsk and Zapolyarnyy) and Norilsk in Northern Siberia were identified as major sources of anthropogenic pollution within the Arctic (Heidam et al., 1999, 2004; Christensen, 1997) in addition to other anthropogenic emissions from the industrial sector, power generation and transport activities in the Arctic cities of Russia. Furthermore, there are also direct and indirect emissions resulting from exploitation of oil and gas in the region (Gautier et al., 2009) as well as ship emissions including cargo transport, tourist cruise and fishing vessels (Odemark et al., 2012).

In order to develop strategies for controlling and reducing Arctic air pollution, there is a need to understand the basic mechanisms for determining the fate of Arctic air pollution, such as long-range transport, transformation of gaseous and particulate species and their partitioning between the gas and particle phase. In addition, the nature and source origin of anthropogenic compounds contributing to Arctic air pollution must be investigated. This study presents analyses of data from 2008-2010 at the high Arctic site Station Nord in North East Greenland using two statistical receptor models; Positive Matrix Factorization (PMF) and the COnstrained Physical REceptor Model (COPREM). The measured concentrations can be considered as a remote indicator from which the average emissions of a massive emission region in the Eastern part of Europe and Russia can be followed (Heidam et al., 2004).

\section{Methods}

\subsection{Measurement site}

The measurement hut "Flygers Hut" at Station Nord $\left(81^{\circ} 36^{\prime} \mathrm{N}, 16^{\circ} 40^{\prime} \mathrm{W}, 30 \mathrm{~m}\right.$ a.s.l.) is located $2.5 \mathrm{~km}$ South East of the Danish military Station at North East Greenland (Fig. 1). At this latitude, the polar day prevails from mid-April to the beginning of September, and the polar night lasts from mid-October to the end of February. Flygers Hut is the main site for the Danish contribution to the atmospheric part of the Arctic Monitoring and Assessment Programme (AMAP). It is supplied by electricity from a local JET A1 fuel generator at Station Nord. The location was selected due to the insignificant contribution from local air pollution and has been described elsewhere (Skov et al., 2004). Only a few episodes of waste burning from the military camp were identified to influence the measurements in the summertime (Heidam et al., 2004). Measurements at Station Nord have been conducted since 1990 and since 1994 as part of the official AMAP programme. The local wind is dominated by South West directions, with highest wind velocities originating from North West and South West (Fig. 2). The analysis is based upon one year wind data obtained from a sonic anemometer (METEK, USA-1, heated) from 31 May 2011 to 1 June 2012, but the data coverage is less in the winter month due to frost on the anemometer. An analysis of winter data (November-March), however, also reveals dominating South-Westerly winds (Fig. 2). The wind flow is probably influenced by regional topography with katabatic winds from the ice caps flowing out along the fjord located South West of Station Nord.

\subsection{Instrumentation}

At Station Nord, a comprehensive list of different compounds is measured and described elsewhere (Heidam et al., 2004). Additionally, a custom-built Particle Soot Absorption Photometer (PSAP) was set up in 2008 to derive black carbon mass concentrations based on measurements of the absorption coefficient of the ambient aerosol. While the calibration of the PSAP is on-going, a preliminary specific absorption coefficient is applied in the present study. The specific absorption coefficient was found via a comparison between the 
Table 1. Analytical methods and sample frequency of measured parameters.

\begin{tabular}{|c|c|c|c|}
\hline $\begin{array}{l}\text { Parameter } \\
40 \mathrm{~mm} \text { FP nitro cellulose filters }\end{array}$ & Analytical method & $\begin{array}{l}\text { Time } \\
\text { resolution }\end{array}$ & Uncertainty \\
\hline $\begin{array}{l}\mathrm{Al}, \mathrm{Si}, \mathrm{S}, \mathrm{K}, \mathrm{Ca}, \mathrm{Ti}, \mathrm{V}, \mathrm{Cr}, \mathrm{Mn}, \mathrm{Fe}, \mathrm{Ni} \text {, } \\
\mathrm{Cu}, \mathrm{Zn}, \mathrm{Ga}, \mathrm{As}, \mathrm{Se}, \mathrm{Br}, \mathrm{Rb}, \mathrm{Sr}, \mathrm{Zr}, \mathrm{Pb} \\
\mathrm{SO}_{2}, \mathrm{SO}_{4}^{2-}, \mathrm{Na}^{+}, \mathrm{NH}_{4}^{+}, \mathrm{NH}_{3}, \mathrm{NO}_{3}^{-} \text {, } \\
\mathrm{HNO}_{3}, \mathrm{Br}^{-}, \mathrm{Cl}^{-} \\
\text {PSAP filters }\end{array}$ & $\begin{array}{l}\text { Proton Induced X-ray } \\
\text { Emission (PIXE) } \\
\text { Ion Chromatography }\end{array}$ & $\begin{array}{l}7 \text { days } \\
7 \text { days }\end{array}$ & $\begin{array}{l}18 \% \\
20 \%\end{array}$ \\
\hline $\begin{array}{l}\text { Black carbon } \\
\text { On-line gas monitors }\end{array}$ & $\begin{array}{l}\text { Particle Soot Absorption } \\
\text { Photometer (PSAP) }\end{array}$ & $15 \mathrm{~min}$ & $20 \%$ \\
\hline $\mathrm{O}_{3}, \mathrm{NOx}, \mathrm{SO}_{2}$ & Gas monitor & $30 \mathrm{~min}$ & $20 \%$ \\
\hline
\end{tabular}

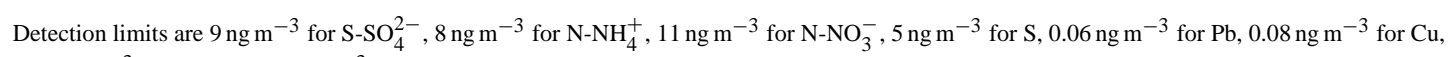
$0.10 \mathrm{ng} \mathrm{m}^{-3}$ for $\mathrm{Ni}$ and $0.05 \mathrm{ng} \mathrm{m}^{-3}$ for As.
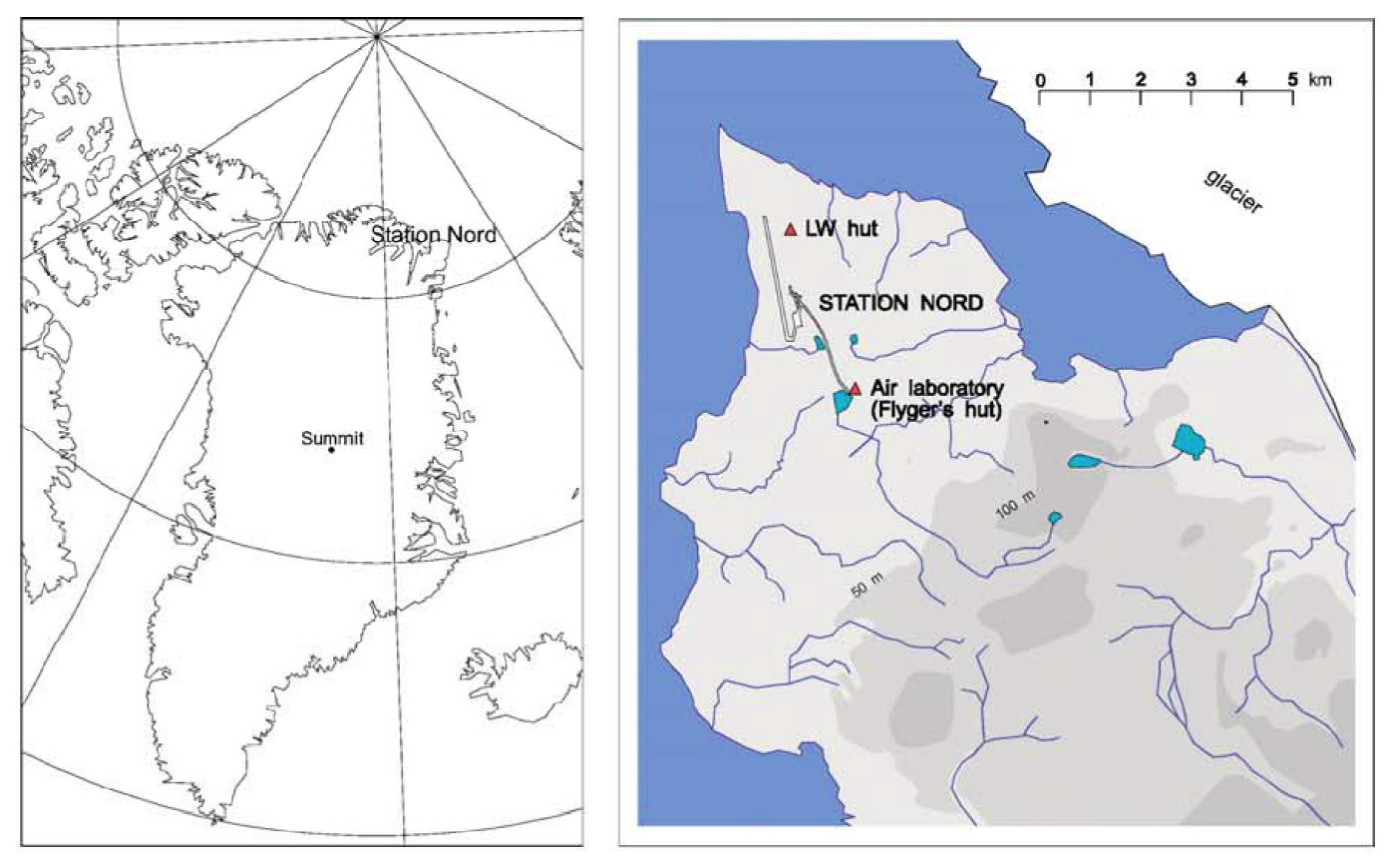

Fig. 1. The Arctic measurement site Station Nord in North East Greenland $\left(81^{\circ} 36^{\prime} \mathrm{N}, 16^{\circ} 40^{\prime} \mathrm{W}\right)$.

PSAP and Elemental Carbon (EC) measurements in field at Station Nord.

Filter pack sampler (FPS) collects total suspended particles with an approximate cut-off diameter of $20 \mu \mathrm{m}$ depending on wind speed. The sampler consists of a sequence of 3 filters, of which the first collects particulate matter. The subsequent filters are impregnated to collect specific gases, notably $\mathrm{SO}_{2}$. The particle filters are analysed for the sulphate $\left(\mathrm{SO}_{4}^{2-}\right)$-, ammonium $\left(\mathrm{NH}_{4}^{+}\right)$- and nitrate $\left(\mathrm{NO}_{3}^{-}\right)$- ions by ion chromatography. Elements with atom number higher than $\mathrm{Al}$ (Table 1), including particulate sulphur $\mathrm{S}$, particle bound $\mathrm{Br}$ (see Skov et al. 2004) were analysed using Proton Induced X- ray Emission (PIXE), albeit with the exception of $\mathrm{Cl}$ and $\mathrm{Hg}$ which evaporate from the particle filter. Gas filters also collect ammonia $\left(\mathrm{NH}_{3}\right)$ if present and nitric acid $\left(\mathrm{HNO}_{3}\right)$. These nitrogen species may evaporate from the particle filter onto the gas filters, for which reason the sum of the particulate and gaseous fractions, are reported. Sampling runs from Monday 00:00 UTC for one week, equivalent to approximately $400 \mathrm{~m}^{3}$.

Uncertainties are listed in Table 1. 

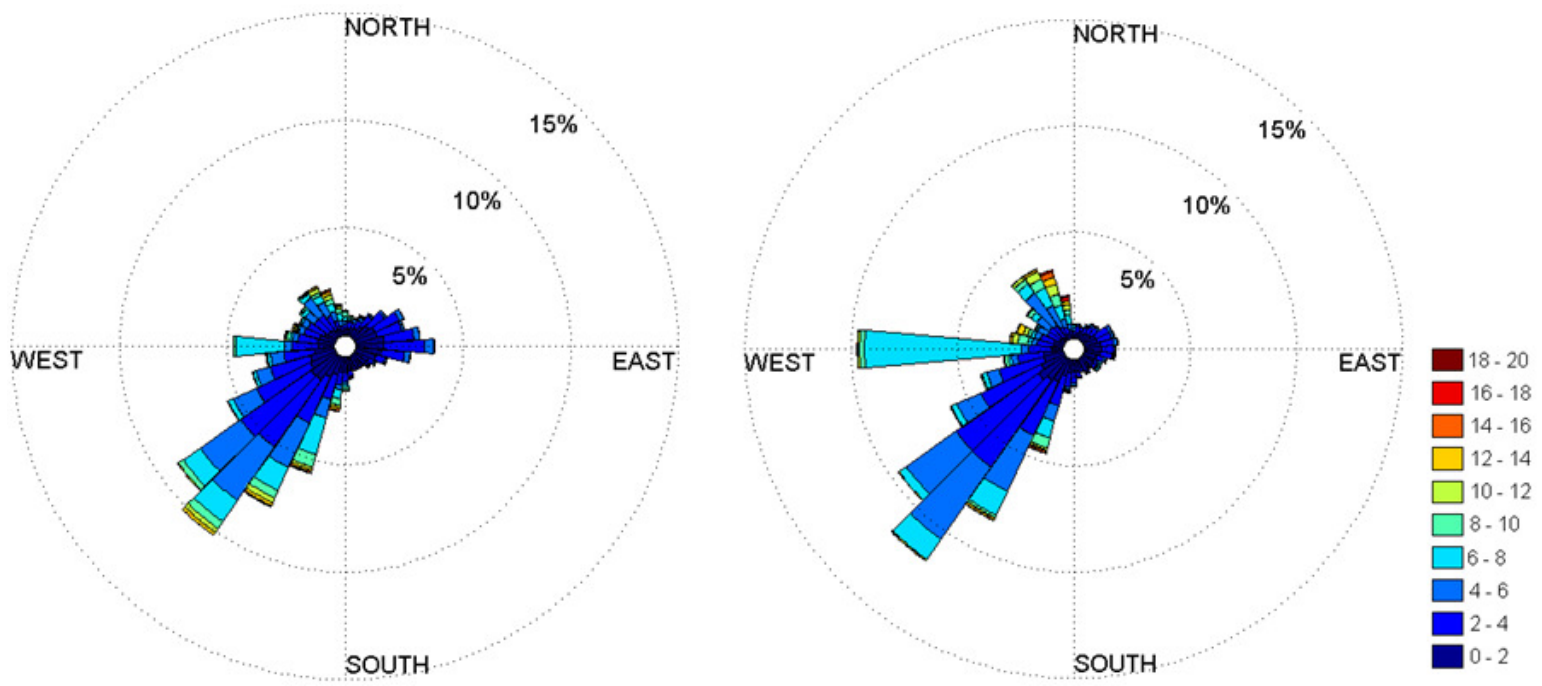

Fig. 2. Windrose showing local wind direction from 31 May 2011 to 1 June 2012 (left) and winter, (November-March 2012) (right). The intensity scale is shown in $\mathrm{ms}^{-1}$.

\subsection{Receptor modelling}

In general, two types of models are used for source apportionment of aerosols, including source-oriented models and receptor models (Schauer et al., 1996). The source-oriented models employ emission data inventories and calculate transport modes (such as dispersion, deposition and trajectories) to estimate the emission, formation, transformation, transport and deposition of aerosols at receptor sites (Eldering and Cass, 1996). Although the models can be very useful especially in scenario studies where emission abatement strategies are evaluated, the use of this type of models is often limited by the availability and reliability of the emission inventories (Viana et al., 2008). In contrast, the receptor models assume that the observed concentrations can be adequately explained by a linear combination of a number of sources with fixed source profiles and variable source strengths in time. In this work, we use two different source apportionment models, i.e. Positive Matrix Factorization (PMF) and the COnstrained Physical REceptor Model (COPREM) to evaluate the sources of Arctic particulate matter at Station Nord over a period of two years from March 2008 to February 2010. The obtained factors of the PMF solution and the obtained sources of the COPREM solution will be both referred to as "source" in this work.

\subsection{PMF}

PMF is a multivariate factor analysis tool, which derives a source contribution matrix $\mathbf{g}$, and a source strength matrix $\mathbf{f}$
(Paatero, 1997) based on measured mass concentrations of selected species and weighted by analytical uncertainty.

$x_{i j} \cong \sum_{k=1}^{p} g_{i k}+e_{i j}$

where $x_{i j}$ is the observed mass concentration of compound $i$ in sample $j, p$ is the number of sources that contribute to $x_{i j}, g_{i k}$ is the source contribution (or source score), $f_{k j}$ is the mass fraction (or source loading), and $e_{i j}$ is the residual or error (Hopke, 2003). The results are constrained to physically possible solutions, which imply that a sample cannot have a negative contribution from a source. Moreover, each data point can be weighted individually, e.g. by regulating the uncertainty of the corresponding measured values below the detection limit so that they have less influence on the resulting solution. The PMF solution minimizes the function $Q$ :

$Q=\sum_{i=1}^{n} \sum_{j=1}^{m}\left[\frac{x_{i j}-\sum_{k=1}^{p} \mathbf{g}_{i k} \mathbf{f}_{k j}}{u_{i j}}\right]^{2}$,

where $u_{i j}$ is the analytical uncertainty of $x_{i j}$. Hence, this is a least square problem to identify the matrices $\mathbf{g}$ and $\mathbf{f}(\mathrm{Xie}$ et al., 1999). The uncertainty of the PMF solution can be estimated by generating new data sets, which are consistent with the original one. Each data set is then decomposed to a $\mathbf{g}$ and $\mathbf{f}$ matrix, which are compared with the base run (Eberly, 2005). 
In this study we used PMF 3.0 provided by the US EPA, which is based on the second version of the Multi linear Engine (ME-2).

\subsection{COPREM}

The data was also analysed using the multivariate receptor model COPREM (Wåhlin, 2003; Heidam et al., 2004; Skov et al., 2006). Like any receptor model, COPREM is based on the assumption that the observed mass concentrations at the receptor site can be explained by contributions from a number of sources with constant source profiles, but variable source strengths in time.

$x_{i j} \cong \sum_{k} a_{i k} f_{k j}$,

where $x_{i j}$ is the measured mass concentration of compound $i$ in sample $j . k$ is the number of sources, which are required to adequately describe the observations. $a_{i k}$ is the fixed profile, and $f_{k j}$ is the source strength in the individual samples. COPREM may be perceived as a hybrid receptor model between PMF and chemical mass balance (CMB), where COPREM resembles PMF or CMB dependent on the number of constraints. If COPREM is operated with a minor number of constraints, the model will resemble PMF, which requires no prior knowledge of the sources (Baltensperger and Prevot, 2008). As a result, $x_{i j}$ in Eq. (3) is the only necessary input though a substantial amount of data is required to infer the sources. In contrast, the sources can be attributed to even small data sets in CMB, as the user can apply constraints and define the source profiles in the receptor model.

COPREM requires three input matrices: a $(2 \times n \times N)$ matrix with measurement data including analytical uncertainty, a $(n \times p)$ source profile matrix and a $(n \times p)$ form matrix defining additional constraints. In the source matrix, the user defines the source profiles (columns) by the ratio of the source elements (rows), e.g. as the percentage of particulate matter $(\mathrm{PM})$. In the form matrix, the user can define additional constraints. The form matrix has the same number of rows and columns as the source matrix, and elements are set to either " 0 " or " 1 ". If the profile elements are set to " 0 ", such elements are fixed in the ratios defined in the source profile, taking the analytical uncertainty into account, whereas if such elements are set to "1", a solution is allowed where the particular elements can be solved different from the values defined in the source profile. The latter is particularly useful, where knowledge of the relevant sources is limited or unknown. Furthermore, specific elements can be excluded from a particular source by setting the concentration to " 0 " in the source profile and " 0 " in the form matrix.

Equation (3) is solved by an iterative method to determine $a_{i k}$ and $f_{k j}$, while taking the uncertainty $\sigma_{i j}$ of the measurements into account. Chi-square statistics provide the squared difference between measurement and model results.
$X^{2}=\sum_{j} \sum_{i} \frac{\left(x_{i j}-\sum_{k} a_{i k} f_{k j}\right)^{2}}{\sigma_{i j}^{2}}$,

Negative coefficients in the source profile and negative source strengths are excluded by built-in constraints in COPREM. The Chi-square is minimized until it reaches a stagnant minimum value during the iteration process within the constraint limits.

The uncertainty of the fitted source profiles in COPREM is estimated with a specific module using weighted linear regression between the calculated source strengths and the measured data, taking into account the analytical uncertainties of the individual species, which are multiplied by a constant factor $\sqrt{\frac{x^{2}}{v}}$, where $v$ is the degree of freedom. However, the calculated uncertainty represents a lower estimate, since other uncertainties may also influence the fitted source profiles (e.g. constraints which are not correctly assigned or by the use of insufficient number of sources).

COPREM fills up a gap in source apportionment analysis as the user-defined constraints can transform the model from either multivariate to strictly CMB. This property is convenient when the analyst has sound knowledge about the source compositions and wishes to partly control the solution based on this knowledge. Other sources may be less understood and the analyst can loosen the constraints on a particular source profile. In contrast, the possibility of COPREM to resemble CMB may become a true disadvantage, if the source profiles fail to meet the actual ones. By combining PMF and COPREM, the analyst can critically evaluate present knowledge of contributing sources.

Soil and Marine profiles corresponding to elemental abundances in igneous rocks (Kaye and Laby, 1959) and seawater (Sverdrup et al., 1942) were used in the COPREM source profiles. The Soil profile was fully constrained. The Marine profile was also constrained except for $\mathrm{Cl}, \mathrm{V}, \mathrm{S}, \mathrm{SO}_{\mathrm{x}}, \mathrm{BC}$ and $\mathrm{Br}$ (Table S1). No constraints were imposed on the anthropogenic profiles, since the knowledge of these sources is scarce. In this regard, the apportionment of the anthropogenic sources in COPREM and PMF followed a strictly mathematical solution free of constraints imposed by the analyst, though the degrees of freedom were larger in PMF, where the natural sources were not constrained.

\section{Results and discussion}

Source apportionment on Arctic aerosols is typically confined to a limited number of sources due to scarce numbers of contributing emission sources in the Arctic as well as unique meteorology and transport mechanisms characteristic for these remote regions. Furthermore, low concentrations of species necessitate longer sampling times (e.g. days to weeks 


\section{PMF}
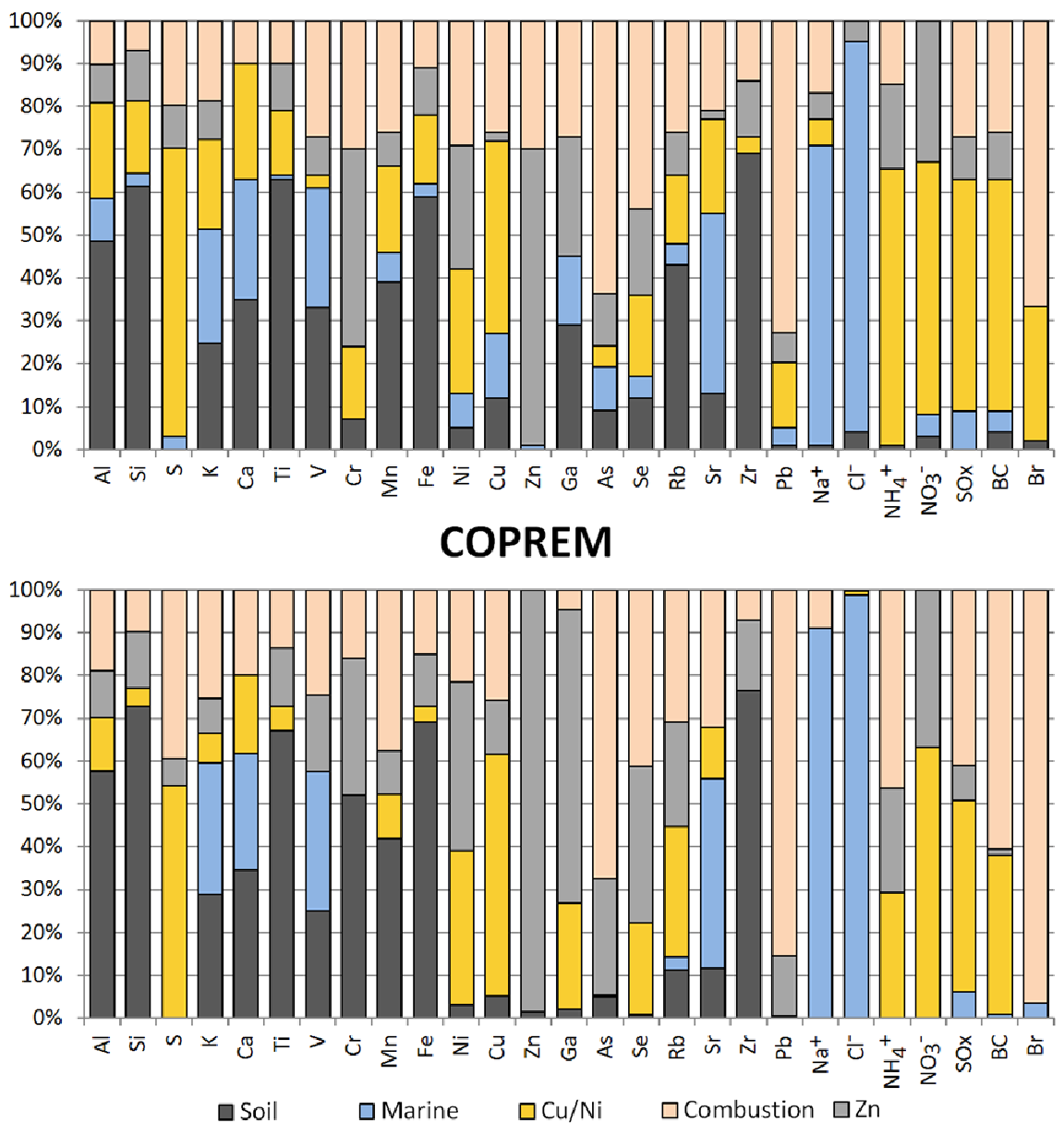

Fig. 3. Source origin of chemical species apportioned by PMF and COPREM.

depending on sampling and analysis technique), which may not allow for the differentiation between sources during nonstationary meteorological conditions. Four sources were sufficient in a COPREM analysis to account for the sources contributing to the aerosols load at Station Nord from 19912001, including a crustal source (soil), a marine source (sea), a metal source $(\mathrm{Cu}$ and $\mathrm{Ni}$ production within the Arctic region) and a combustion source representing various distant anthropogenic activities (Heidam et al., 2004). In a study by Xie et al. (1999) using PMF, five sources were required to account for the Arctic aerosols measured at Alert, Northwest Territories, Canada, from 1980-1991. Only one anthropogenic factor was identified. In the present study, at least five sources were necessary to adequately explain the measurements of particulate composition at Station Nord from March 2008 to February 2010. Data was analysed with and without $\mathrm{Br}, \mathrm{S}$ and $\mathrm{SO}_{\mathrm{x}}$. Similar to $\mathrm{Cl}, \mathrm{Br}$ may evaporate as $\mathrm{HBr}$ upon acidification of the aerosol, or partly act as a secondary pollutant (Mcconnell et al., 1992), which may disturb the apportionment of primary sources. In addition, the season-dependent $\mathrm{OH}$ oxidation of $\mathrm{SO}_{2}$ to $\mathrm{H}_{2} \mathrm{SO}_{4}$ calls for special attention on sulphur species in source apportionment, for which reason we account for the sulphur species by introducing the parameter $\mathrm{SO}_{\mathrm{x}}=\mathrm{SO}_{2}+\mathrm{SO}_{4}^{2-}$. We concluded that inclusion of $\mathrm{SO}_{\mathrm{x}}$ and $\mathrm{Br}$ supported the source apportionment.

Initially, four sources were fitted to the data with a constrained soil profile, a partially constrained marine profile and two unconstrained profiles in COPREM analysis, following Heidam et al. (2004). However, high $\mathrm{Chi}^{2}$ numbers (Wåhlin, 2003) and poorly fitted data were also observed, particularly with $\mathrm{S}, \mathrm{As}, \mathrm{Pb}$ and $\mathrm{Br}$ species in addition to unaccounted episodes of elevated concentration of $\mathrm{Zn}$ especially during summer 2009. Further investigation of longterm trend of $\mathrm{Zn}$ concentration also revealed a higher range of concentrations during our study period in comparison to the years 1991-2001 covered in Heidam et al. (2004). Nonconverging solutions and poorly fitted data also resulted from PMF analysis. This indicates that a four-source solution is no longer sufficient. In fact, satisfactory fits were achieved from a five-source solution with two natural sources (Soil and 

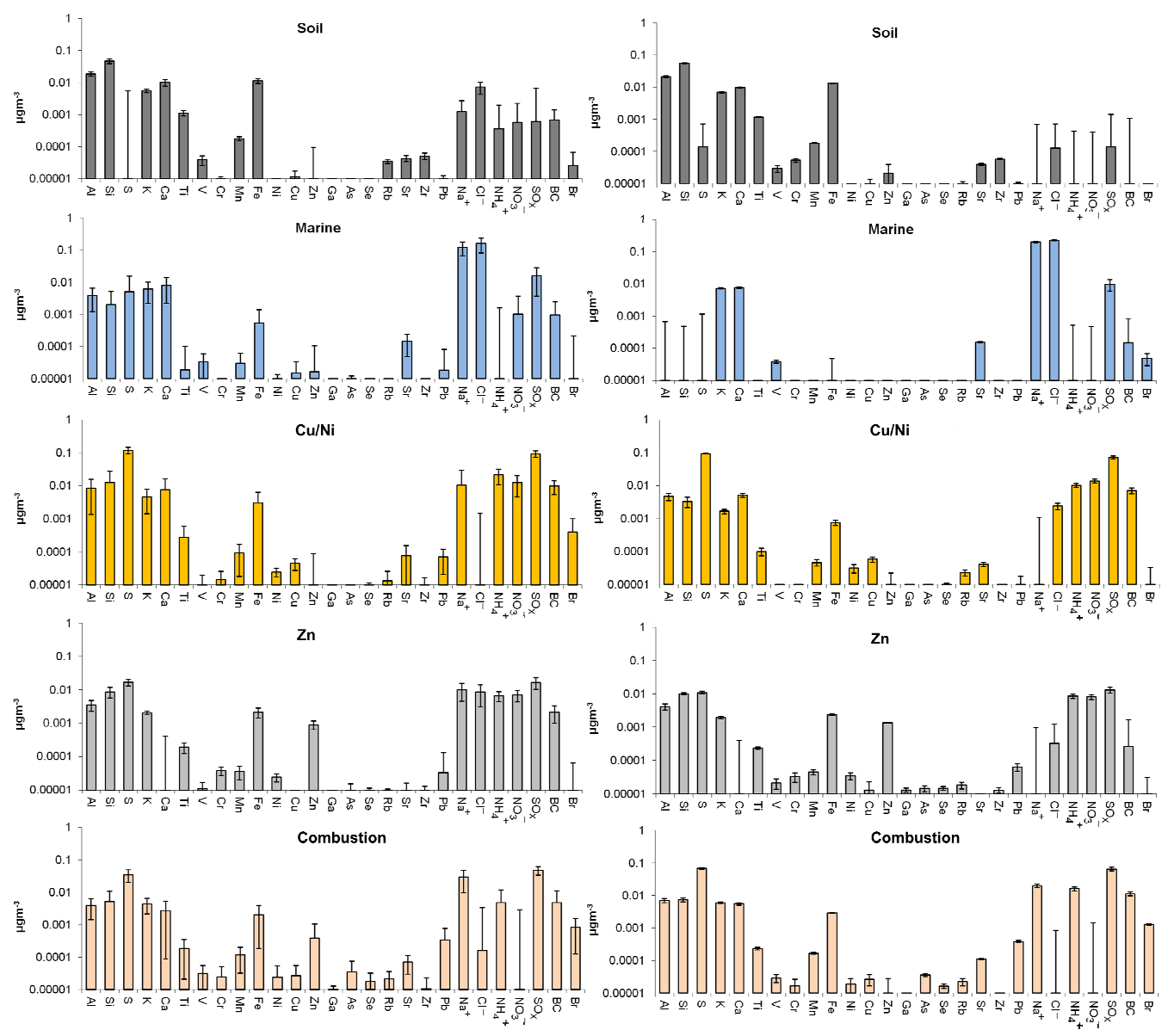

Fig. 4. Concentration $\left(\mu \mathrm{g} \mathrm{m}^{-3}\right)$ and uncertainty (standard deviation) of species in PMF (left) and COPREM (right) profile.

Marine source) and three anthropogenic sources dominated by the metals $\mathrm{Cu} / \mathrm{Ni}, \mathrm{Zn}$ and $\mathrm{Pb} / \mathrm{As}$, respectively (Figs. 34, Table S2). Compared to the previous solution proposed by Heidam et al. $(1999,2004)$ for Station Nord, the $\mathrm{Cu} / \mathrm{Ni}$ source in our study resembles the previous metal source and our Combustion source probably resembles the previous combustion source whereas $Z n$ source is a newly added one. Concentration and standard deviation of the PMF and COPREM profiles are shown in Fig. 4. Q (robust) for the base run was 7340. In order to check the stability of the solution, 100 bootstrap runs were completed of which all converged. $\mathrm{Q}$ (robust) varied from 4441-7537 with 25th quartile: 6031, median: 6382 and 75 th quartile: 6780 . Fpeak runs of strength $0.1-0.5$ resulted in Q-values from 7145-7249. The calculated total $\mathrm{Chi}^{2}$ statistic for the COPREM solution is 10683 for total 27 species.

Table 2 shows concentrations of the analysed species at Station Nord during the study period. Due to the frequent influence of the Arctic Haze pattern resulting in elevated concentrations during winter for many species, the reported mean and median values maybe in the higher range for summer concentrations and in the lower range for winter con- centrations. The values however blend well with the concentration range/values for the corresponding species at different sites in the Arctic summarized in Sander and Bottenheim (2012).

\subsection{Natural sources}

The source Soil was dominated by $\mathrm{Al}, \mathrm{Si}, \mathrm{Ca}, \mathrm{Ti}, \mathrm{Mn}, \mathrm{V}$ and Fe (Figs. 3-4, Table S2). A crustal source was previously described as peaking in spring and late summer (Heidam et al., 1999). PMF and COPREM solutions for the Soil source were highly consistent with maximum concentration also observed in spring/summer 2008, though this spring/summer peaking trend was much less pronounced in 2009 (Fig. 5). PMF and COPREM attributed $33 \%$ PMF and $25 \%$ COPREM of total $\mathrm{V}$ to this source, respectively. V is typically associated with fossil oil combustion, but other Arctic studies have associated $\mathrm{V}$ with the crustal source (Heidam et al., 2004; Maenhaut and Cornille, 1989) and V occurs in about 65 different minerals (Wang and Sañudo Wilhelmy, 2009). Notable differences $(>20 \%)$ in the PMF and COPREM solutions for the Soil source are seen for $\mathrm{Rb}\left(43 \%_{\mathrm{PMF}} ; 11 \%_{\mathrm{COPREM}}\right)$ and $\mathrm{Cr}$ 
Table 2. Concentration of analysed species $\left(\mathrm{ng} \mathrm{m}^{-3}\right)$ at Station Nord during the period 3/2008-2/2010.

\begin{tabular}{|c|c|c|c|}
\hline Compound & Mean/ng m ${ }^{-3}$ & Median/ng m ${ }^{-3}$ & $\begin{array}{l}\text { Highest concentration } \\
\text { observed } / \mathrm{ng} \mathrm{m}^{-3}\end{array}$ \\
\hline $\mathrm{Al}$ & 37.9 & 32.7 & 104.6 \\
\hline $\mathrm{Si}$ & 75.5 & 59.3 & 287.6 \\
\hline$S$ & 178.9 & 123.4 & 749.1 \\
\hline K & 23.2 & 19.6 & 68.9 \\
\hline $\mathrm{Ca}$ & 29.7 & 25.0 & 85.5 \\
\hline $\mathrm{Ti}$ & 1.8 & 1.3 & 8.4 \\
\hline V & 0.1 & 0.1 & 0.5 \\
\hline $\mathrm{Cr}$ & 0.08 & 0.06 & 0.4 \\
\hline $\mathrm{Mn}$ & 0.5 & 0.4 & 1.4 \\
\hline $\mathrm{Fe}$ & 19.4 & 14.3 & 67.2 \\
\hline $\mathrm{Ni}$ & 0.1 & 0.06 & 0.9 \\
\hline $\mathrm{Cu}$ & 0.1 & 0.08 & 0.6 \\
\hline $\mathrm{Zn}$ & 1.3 & 1.1 & 5.9 \\
\hline $\mathrm{Ga}$ & 0.02 & 0.02 & 0.09 \\
\hline As & 0.06 & 0.03 & 0.3 \\
\hline $\mathrm{Se}$ & 0.04 & 0.03 & 0.2 \\
\hline $\mathrm{Rb}$ & 0.08 & 0.06 & 0.3 \\
\hline $\mathrm{Sr}$ & 0.4 & 0.3 & 1.7 \\
\hline $\mathrm{Zr}$ & 0.08 & 0.06 & 0.4 \\
\hline $\mathrm{Pb}$ & 0.6 & 0.2 & 3.2 \\
\hline $\mathrm{Na}^{+}$ & 211.3 & 123.1 & 1157.5 \\
\hline $\mathrm{Cl}^{-}$ & 241.3 & 21.0 & 2187.5 \\
\hline $\mathrm{NH}_{4}^{+}$ & 46.8 & 30.6 & 166.0 \\
\hline $\mathrm{NO}_{3}^{-}$ & 29.6 & 24.5 & 124.7 \\
\hline $\mathrm{SO}_{\mathrm{x}}$ & 238.3 & 112.3 & 1028.2 \\
\hline $\mathrm{BC}$ & 19.8 & 12.4 & 108.4 \\
\hline $\mathrm{Br}$ & 1.5 & 0.7 & 7.6 \\
\hline
\end{tabular}

(7 \% PMF $; 52 \%$ COPREM) (Table S2), however, measured concentrations of $\mathrm{Rb}$ were low.

$\mathrm{Na}$ and $\mathrm{Cl}$ are dominating species in the Marine source, which also included $\mathrm{K}, \mathrm{Ca}, \mathrm{Sr}$ and $\mathrm{V}$ (28\% $\mathrm{PMF}$; $33 \%$ COPREM), small amounts of $\mathrm{SO}_{\mathrm{x}}$ (9\% $\%_{\mathrm{PMF}} ; 6 \%$ COPREM) and $\mathrm{BC}$ (5\% $\%_{\mathrm{PMF}} ; 1 \%$ COPREM $)$. The worldwide increasing ship traffic could explain $\mathrm{BC}, \mathrm{SO}_{\mathrm{x}}$ and $\mathrm{V}$ in the natural $\mathrm{Ma}$ rine source. However, $\mathrm{V}$ is also relatively abundant in open ocean waters (Wang and Sañudo Wilhelmy, 2009). The $M a$ rine source shows a clear annual trend with lower summer concentrations and increased contributions in the autumn and winter period (Fig. 5). In the autumn, ocean storms may lead to high productions of sea spray aerosols. During winter, the sea surrounding Station Nord is frozen and thus it is not likely that the aerosols originate from open waters, however it is suggested by Fenger et al. (2012) that large $\mathrm{Cl}^{-}$containing particles at Station Nord can originate from frost flowers torn at high wind speeds. Furthermore a study by Domine et al. (2004) also found that both frost flowers and the marine snow pack can be sources of sea salt.

The PMF and COPREM solutions for the Marine source are fairly similar though the former includes low contribu- tions of additional elements, including $\mathrm{Al}, \mathrm{Si}, \mathrm{Ti}$ and $\mathrm{Fe}$ (Figs. 3-4). The time profiles of PMF and COPREM solutions are also highly similar, with slightly higher contribution of the Marine source during certain intervals of the PMF solution (Fig. 5). The presence of $\mathrm{Al}, \mathrm{Si}$, Ti and $\mathrm{Fe}$ in the PMF source (Fig. 3) suggests that the Marine source is somehow mixed with a crustal source, probably disturbed by the low (weekly) time resolution or complex long-range transport imprinting of the observed samples. $\mathrm{K}$ and $\mathrm{Ca}$ are also found in all sources, except for the $Z n$ source. Indeed, unclear or "blurry" source profiles have been observed in other studies in the Arctic region (Xie et al., 1999). The COPREM solution, on the other hand, is constrained with respect to these elements, which may explain small deviations in the time profiles. $\mathrm{K}$, $\mathrm{Ca}$ and $\mathrm{Sr}$ were assigned to the COPREM input source profile (Table S1), since these elements are abundant in both seawater and aerosols created from sea spray (Maenhaut and Cornille, 1989; Heidam et al., 2004). Except for $\mathrm{V}, \mathrm{S}, \mathrm{SO}_{\mathrm{x}}, \mathrm{Br}$ and $\mathrm{BC}$, all elements in the COPREM input profile were constrained to a seawater composition profile (Sverdrup et al., 1942). Notable differences in the PMF and COPREM solutions are only observed for $\mathrm{Na}(21 \%)$. 


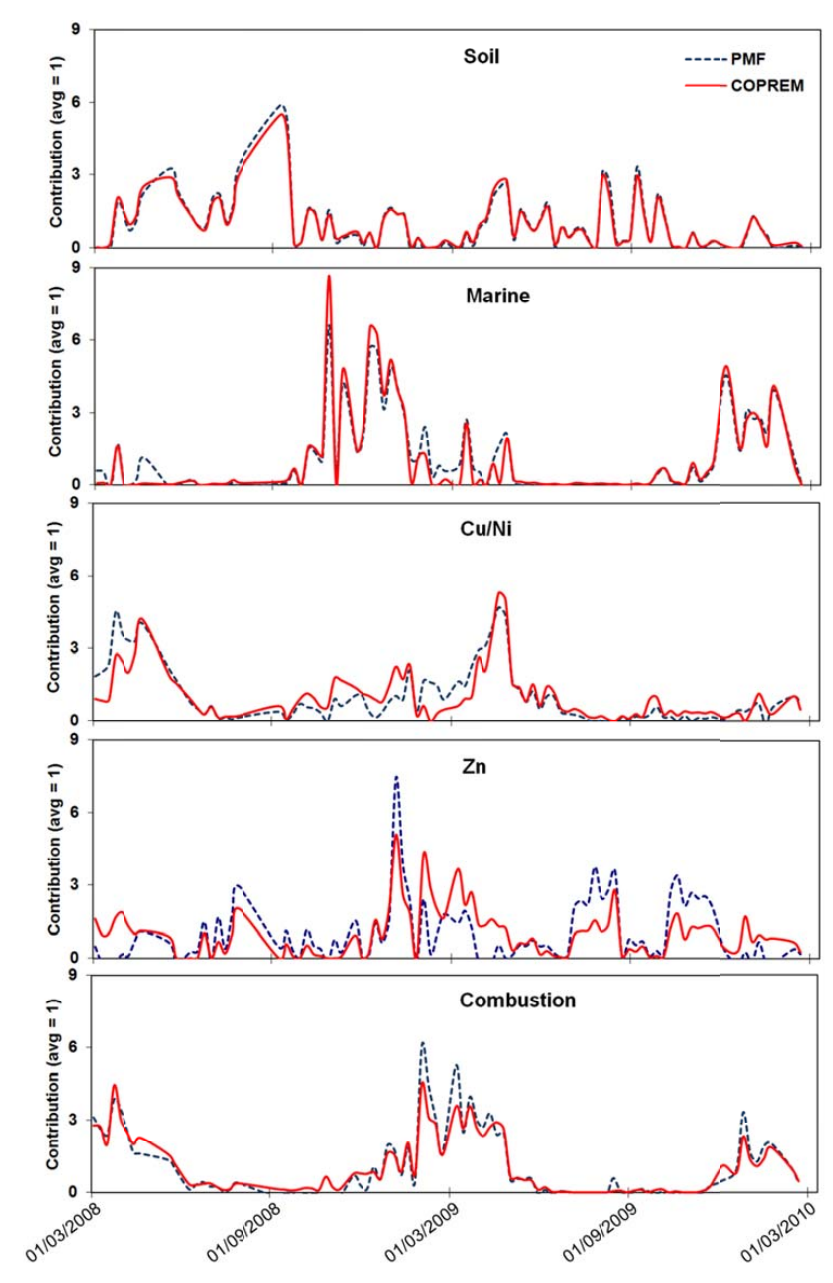

Fig. 5. Time profiles of PMF and COPREM sources.

Se has previously been suggested to originate mainly from marine biogenic sources in the Norwegian Arctic (Maenhaut and Cornille, 1989). However, we find only a negligible marine contribution to $\mathrm{Se}\left(5 \%_{\mathrm{PMF}}\right.$; $\left.0 \%_{\mathrm{COPREM}}\right)$ compared to the anthropogenic sources ( $83 \%$ PMF $; 100 \%$ COPREM).

\subsection{Anthropogenic sources}

Three sources are characterised by high abundances of the elements $\mathrm{Zn}, \mathrm{Cu}, \mathrm{Ni}, \mathrm{Pb}$ and $\mathrm{As}$, which are interpreted as anthropogenic sources or most likely agglomerates of sources. Two sources influenced by metal industry, which includes most notably the $\mathrm{Cu}$ and $\mathrm{Ni}$ smelters on the Kola peninsula (Nikel, Monchegorsk and Zapolyarnyy) and Norilsk in Northern Siberia (Christensen et al., 1997; Heidam et al., 1999, 2004) peaked in spring/summer (Cu/Ni source), and winter (Combustion source). The $\mathrm{Cu} / \mathrm{Ni}$ source is probably an agglomerate of sources from Eurasia as evident from the contribution of $\mathrm{Cu}\left(45 \%_{\mathrm{PMF}} ; 56 \%_{\mathrm{COPREM}}\right)$ and $\mathrm{Ni}\left(29 \%_{\mathrm{PMF}}\right.$; $36 \%$ COPREM). $\mathrm{Cu}$ and $\mathrm{Ni}$ are present in both the $\mathrm{Cu} / \mathrm{Ni}$ and Combustion sources but virtually absent in the natu- ral sources. The impact of $\mathrm{Cu}$ on anthropogenic and natural sources gives evidence that Eurasia, and in particular the Siberian $\mathrm{Cu} / \mathrm{Ni}$ industry, is a major source of pollutants in the higher Arctic. Previously, $\mathrm{Cu}$ has almost exclusively been apportioned to one anthropogenic source with heavy influences from the metal industry, whereas two distinct anthropogenic sources have contributed to $\mathrm{Ni}$ in former studies at Station Nord (Heidam et al., 1999, 2004). The highest abundance of primary and secondary combustion products were attributed to the $\mathrm{Cu} / \mathrm{Ni}$ source by both PMF and COPREM, i.e. $\mathrm{NO}_{3}^{-}$ (59 $\left.\%_{\text {PMF }} ; 63 \%_{\text {COPREM }}\right), \mathrm{SO}_{\mathrm{x}}\left(54 \%_{\mathrm{PMF}} ; 45 \%_{\text {COPREM }}\right)$ and BC (54\% $\left.\%_{\text {PMF }} ; 37 \%_{\text {COPREM }}\right)$, which could reflect combustion processes fuelled by coal, as indicated by Se (19\% $\%_{\mathrm{PMF}}$; $21 \%$ COPREM), and most likely not oil due to the low abundance of V (3\% PMF; $0 \%$ COPREM). Alternatively, the combustion products may originate from power generation and other combustion processes connected to the metal industry near the industrial sites. As mentioned above, we included a parameter $\mathrm{SO}_{\mathrm{x}}$, defined as the sum of $\mathrm{SO}_{2}$ and $\mathrm{SO}_{4}^{2-}$. In this way, we take into account the variable oxidation rate of $\mathrm{SO}_{2}$ to form $\mathrm{SO}_{4}^{2-}$ over the seasons, where the availability of sunlight and thereby $\mathrm{OH}$ is highly variable. However, the results should be taken with caution. A higher deposition velocity of gaseous $\mathrm{SO}_{2}$ as compared to particulate $\mathrm{SO}_{4}^{2-}$ (Possanzini et al., 1988) imply an increased scavenging of $\mathrm{SO}_{2}$ during the darker period of the year and consequently an underestimation of $\mathrm{SO}_{\mathrm{x}}=\mathrm{S}-\mathrm{SO}_{2}+\mathrm{S}_{-} \mathrm{SO}_{4}^{2-}$. Since the source profiles in COPREM and PMF do not change over the season, this would slightly affect the fit of $\mathrm{SO}_{\mathrm{x}}$ to the sources. The majority of $\mathrm{SO}_{\mathrm{x}}\left(54 \%_{\mathrm{PMF}} ; 45 \%_{\mathrm{COPREM}}\right)$ and $\mathrm{NO}_{3}^{-}\left(59 \%_{\mathrm{PMF}} ; 63 \%\right.$ COPREM $)$ are apportioned to $\mathrm{Cu} / \mathrm{Ni}$. The remaining mass of these species is largely found in the $Z n$ source. Although both PMF and COPREM suggest $\mathrm{Cu} / \mathrm{Ni}$ to be the major source of $\mathrm{NO}_{3}^{-}$and $\mathrm{SO}_{4}^{2-}$, recent findings at Station Nord show that the particle modes of $\mathrm{NO}_{3}^{-}$(maximum at $1.2 \mu \mathrm{m}$ ) and $\mathrm{SO}_{4}^{2-}$ particles (maximum at $0.3 \mu \mathrm{m}$ ) are significantly different (Fenger et al., 2012). $\mathrm{H}_{2} \mathrm{SO}_{4}$ which is either formed directly or from oxidation of $\mathrm{SO}_{2}$ by $\mathrm{OH}$, may participate in nucleation processes to form new particles (Napari et al., 2002). In contrast, $\mathrm{HNO}_{3}$ is expected to adsorb onto pre-existing particles and thereby larger particles (FinlaysonPitts and Hemminger, 2000; Song and Carmichael, 1999), which explains why the two species are present in different particle modes despite having the same source origin. The apportionment by PMF and COPREM generally agree well with respect to the abundances of species (Fig. 3-4 and Table S2) and time profiles (Fig. 5). Notable differences are observed for $\mathrm{Si}, \mathrm{Cr}, \mathrm{Fe}, \mathrm{Ga}, \mathrm{Pb}$ and $\mathrm{NH}_{4}^{+}$. Among these species, $\mathrm{NH}_{4}^{+}$is believed to originate from long-range transported husbandry sources and influence all anthropogenic sources.

Also influenced by $\mathrm{Cu} / \mathrm{Ni}$ is the Combustion source, which is characterised by high concentration of $\mathrm{Pb}\left(72 \%_{\mathrm{PMF}}\right.$; $\left.86 \%_{\text {COPREM }}\right)$ and As (63\% PMF; $\left.68 \%_{\text {COPREM }}\right)$. This Combustion source represents typical anthropogenic pollutants 
which are long-range transported to Station Nord (Heidam et al., 1999; Heidam et al., 2004). High abundances of V (27\% $\left.\%_{\text {PMF }} ; 25 \%_{\text {COPREM }}\right)$ and Se $\left(44 \%_{\text {PMF }} ; 41 \%\right.$ COPREM $)$ indicate oil and coal fuelled industry and/or other anthropogenic combustion processes. Primary and secondary combustion products also appear with high abundances (Fig. 34). As and Se have previously been apportioned to sources from the Kola Peninsula (Maenhaut and Cornille, 1989). $\mathrm{NO}_{3}$ which is the oxidation product of $\mathrm{NO}_{\mathrm{x}}$ is however absent from this Combustion source, which is possibly due to the smaller contribution of the species from this source compared to the other two anthropogenic $\mathrm{Cu} / \mathrm{Ni}$ and $\mathrm{Zn}$ sources.

$\mathrm{Br}\left(66 \%_{\mathrm{PMF}} ; 96 \%_{\mathrm{COPREM}}\right)$ is largely apportioned to the Combustion source and plays a key-role in ozone depletion during Arctic sunrise, though the activation of bromine is not fully understood (Sumner and Shepson, 1999). It has previously been suggested that sea-salt bromine may be accumulated in the snowpack during the long polar night and is evolved as $\mathrm{Br}_{2}$ into the atmosphere at polar sunrise (Mcconnell et al., 1992). In the following step, $\mathrm{BrO}$ is formed in the reaction with $\mathrm{O}_{3}$ and $\mathrm{Br}$ atoms from photolysis of $\mathrm{Br}_{2}$, or e.g. $\mathrm{HOBr}$ from the reaction of $\mathrm{BrO}$ with the $\mathrm{HO}_{2}$ radical (Impey et al., 1999). Br may also react with organic compounds to form $\mathrm{HBr}$ and organic bromine compounds, all of which are suspected to be scavenged by Arctic aerosols (Mcconnell et al., 1992; Impey et al., 1997, 1999). Furthermore, $\mathrm{Br}_{2}$ can recycle with or without $\mathrm{O}_{3}$ (Impey et al., 1999; Simpson et al., 2007) and may photolyse to $\mathrm{Br}$ atoms which further deplete $\mathrm{O}_{3}$. In addition to the Combustion source, $\mathrm{Br}$ is apportioned to $\mathrm{Cu} / \mathrm{Ni}$ source $\left(31 \%_{\mathrm{PMF}} ; 0 \%_{\mathrm{COPREM}}\right)$ and virtually no other sources, though the $\mathrm{Br}$ has both natural sources, e.g. sea-salt and marine organisms (Gribble, 2000) and anthropogenic sources, e.g. incineration and chemical industries (Morawska and Zhang, 2002). An anti-correlation is apparent between $\mathrm{Br}$ and $\mathrm{O}_{3}$ in 2009 from about polar sunrise in the beginning of March until beginning of June (Fig. 6), after which $\mathrm{Br}$ decreases, which is in agreement with previous observations at Station Nord (Skov et al., 2004). Br is only low during summer and increases to $\mathrm{ng} \mathrm{m}^{-3}$ levels from November-December (Fig. 6). We assume that this is due to oceanic storms, since the Marine source peaks earlier than bromine concentrations (Figs. 5-6). Br is mainly apportioned (96\%) to Combustion using COPREM. Using PMF, this source accounts for $66 \%$ whereas $\mathrm{Cu} / \mathrm{Ni}$ source accounts for additional $31 \%$ (Table S2). Apparent from Fig. 6, $\mathrm{Br}$ resembles the anthropogenic elements $\mathrm{Pb}$ and $\mathrm{S}$, which can probably be explained by $\mathrm{S}$ acting as a "transport container" in addition to $\mathrm{S}$ as $\mathrm{H}_{2} \mathrm{SO}_{4}$ being a source of $\mathrm{H}^{+}$. In other words, $\mathrm{Br}$ is most unlikely emitted from anthropogenic sources, but probably has marine sources (Simpson et al., 2007).

The $\mathrm{Zn}$ source appears to have a different origin than $\mathrm{Cu} / \mathrm{Ni}$ and Combustion source, since it is only influenced by $\mathrm{Cu}$ to a minor extent. According to Heidam et al. (2004), Zn together with $\mathrm{Pb}$ and As were mostly attributed to the combus- tion source. Compared to the work by Heidam et al. (2004) based on data from 1991-2001, the present work analyses a shorter but more recent data set from 3/2008-2/2010 with a larger number of chemical parameters. A separate COPREM analysis is also conducted to investigate whether the inclusion of an additional anthropogenic source is necessary based on previous source results from Heidam et al. (2004) both with and without the additional chemical parameters. According to this, $\mathrm{Zn}, \mathrm{Pb}$ and As could no longer be adequately explained using a single common source, which consequently indicates that the sources have changed. The apportionment by PMF and COPREM to $Z n$ source as the largest source of Zn (69\% PMF $_{\text {P }} 98 \%$ COPREM) to Station Nord agrees well. $Z n$ source also accounts for Arctic summer periods, where the contribution of anthropogenic elements was high (Fig. 5), which was not observed earlier at Station Nord (Heidam et al., 1999; Heidam et al., 2004). In this source, $\mathrm{Br}$ is absent whereas $\mathrm{SO}_{\mathrm{X}}\left(10 \%_{\mathrm{PMF}} ; 8 \%_{\mathrm{COPREM}}\right)$ and $\mathrm{S}\left(10 \%_{\mathrm{PMF}} ; 6 \%_{\mathrm{COPREM}}\right)$ are low in comparison with the Siberian sources imprinted with abundant Brand S. While this stresses the difference of this $Z n$ source compared to the other two anthropogenic sources $\mathrm{Cu} / \mathrm{Ni}$ and Combustion, it also supports the hypothesis of $\mathrm{S}$ acting as a transport container for Br. Only minor differences in the apportionment of other species to this $Z n$ source are observed between PMF and COPREM (Table S2). Finally, all anthropogenic sources are influenced by Se (19-44\%), indicative of coal-fuelled processes (Sholkovitz et al., 2009) (Figs. 3-4, Table S2).

In order to investigate the origin of the $Z n$ source, the HYSPLIT model is used to generate air mass back trajectories. Back trajectories are calculated for arrival at $50 \mathrm{~m}$ and $500 \mathrm{~m}$ above sea level every $24 \mathrm{~h}$ during the Arctic summer periods where there was sudden elevation of $\mathrm{Zn}$ concentration or consistently high $\mathrm{Zn}$ concentrations. As the back trajectories are calculated 10 days backwards due to the remote location of Station Nord whereas the associated uncertainty increases dramatically with time, implications of back trajectory results must be interpreted with caution. Calculated air masses from the back trajectories seem to arrive from various directions, including West of Station Nord (Canadian Arctic, North America and West Greenland), North of Station Nord (the North Pole and Siberia) and South of Station Nord (North Atlantic over Greenland) (Fig. 7). However it was revealed that a change in air mass direction to Westerly origins of Station Nord (Canadian Arctic, North America, and West Greenland), especially from Canadian Arctic is often accompanied with an elevated concentration of $\mathrm{Zn}$, thereby indicating a $Z n$ source from this region. In contrast, there are also high $\mathrm{Zn}$ concentrations associated with air masses arriving from other directions, including the North Atlantic over Greenland and Siberia which are observed less frequently than air masses originated from Westerly directions of Station Nord.

A possible $\mathrm{Zn}$ source could be the Canadian Arctic Archipelago mine in Baffin, near the Arctic Bay, which is 


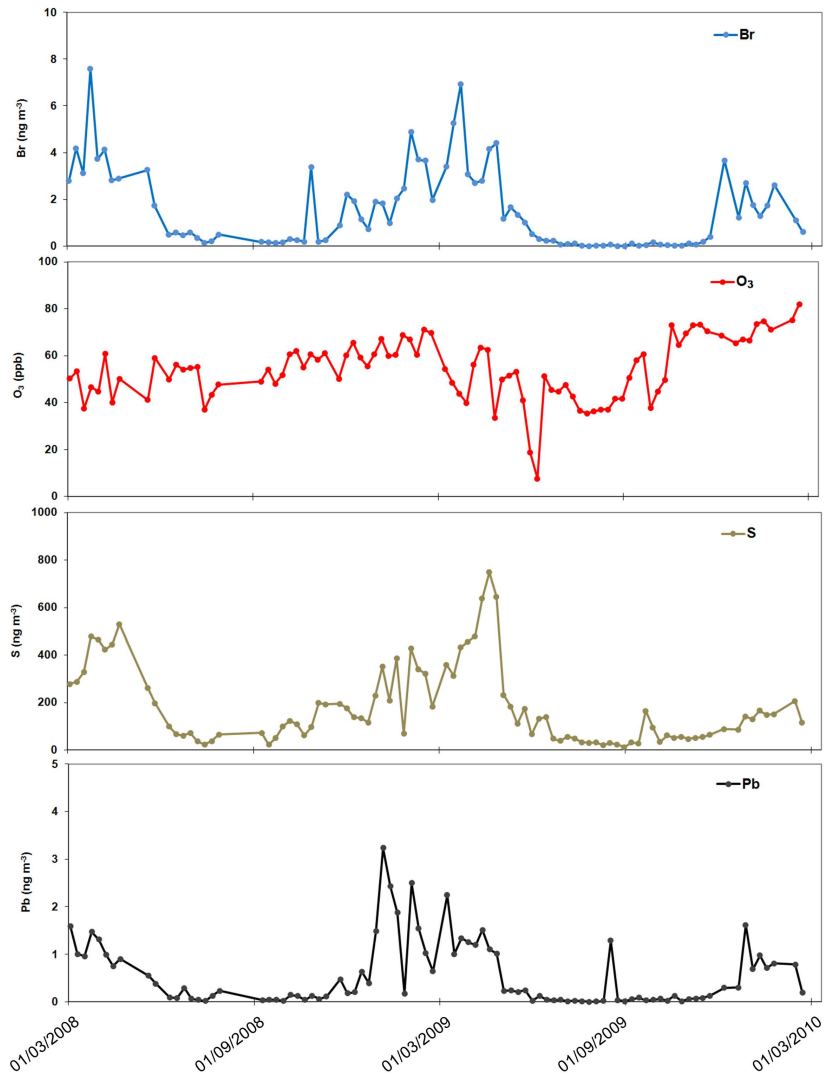

Fig. 6. Time profiles for $\mathrm{Br}, \mathrm{O}_{3}, \mathrm{~S}$ and $\mathrm{Pb}$. $\mathrm{Br}$ correlates with $\mathrm{S}$ and $\mathrm{Pb}$ throughout the observation period. $\mathrm{Br}$ anti-correlates with $\mathrm{O}_{3}$ from about polar sunrise in the beginning of March until beginning of June in 2009, after which $\mathrm{Br}$ decreases.

the major $\mathrm{Zn}$ mine closest to Station Nord. The mine is also located in the region of trajectories associated with elevated $\mathrm{Zn}$ concentration. In addition to $\mathrm{Zn}, \mathrm{Cu}$ and $\mathrm{Pb}$ are also produced at this mine (AMAP, 1997). Whereas a certain percentage of $\mathrm{Pb}$ was assigned to the $\mathrm{Zn}$ source $(7 \% \mathrm{PMF}$; $14 \%$ COPREM), the assignment of $\mathrm{Cu}$ to this source was more limited regarding the PMF solution ( $2 \%_{\mathrm{PMF}} ; 13 \%$ COPREM). Further source discussion is hindered by the lack of production data of the mine. In addition, a gap in available monitoring data between the period 1991-2001 covered in Heidam et al. (2004) and the period 3/2008-2/2010 covered in this study further impedes a direct trend evaluation of emitted $\mathrm{Zn}$ especially over the gap of preceding years 2002-2007 compared to the recent year. Li and Cornett (2011) also reported a long-term increase in zinc concentration in the Canadian Arctic and Sub-Arctic air resulting from studying particulate samples collected at various sites in Canada during 19732000. A increasing trend of $\mathrm{Zn}$ concentrations were found at many sites, most significant at Coral Harbour $\left(64^{\circ} 12^{\prime} \mathrm{N}\right.$, $83^{\circ} 18^{\prime} \mathrm{W}$ ) which is not in proximity of any major $\mathrm{Zn}$ mine, which has prevented them from linking Arctic $\mathrm{Zn}$ mining to the observed trend. The reported period of the observed increasing trend was clearly more dated than our study period.

BC is mainly apportioned to anthropogenic sources ( $80 \%_{\mathrm{PMF}} ; 98 \%_{\mathrm{COPREM}}$ ), and predominantly found to have Siberian origin. Whereas COPREM assigns a higher percent-

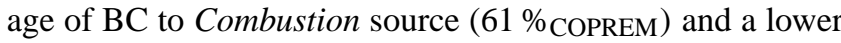
percentage to $\mathrm{Cu} / \mathrm{Ni}$ source ( $37 \%$ COPREM), the PMF solution suggests a lower percentage to Combustion (26\% $\mathrm{PMF}$ ) compared to $\mathrm{Cu} / \mathrm{Ni}$ source $(54 \% \mathrm{PMF})$. PMF also apportioned a certain higher amount of BC (10\% $\left.\%_{\mathrm{PMF}}\right)$ to $Z n$ source compared to COPREM (1\% COPREM). Despite such differences between PMF and COPREM, the high contribution from Siberian metal industries to BC at Station Nord is inevitable, which agrees with other recent findings (Hirdman et al., 2010; Wang et al., 2011).

\subsection{Comparison of PMF and COPREM}

Using a combination of PMF and COPREM in analysing the same data set provides certain advantages. First, we are able to achieve fairly reliable solutions of the better-defined natural Soil and Marine sources using COPREM. Such solutions also serve to identify the corresponding Soil and Marine sources from the PMF solution among the initially unidentified sources. Second, the anthropogenic sources of COPREM can be compared with the remaining PMF sources to determine the corresponding match of COPREM and PMF sources, though it should be expected that the solution for the anthropogenic sources using COPREM in principle should fairly resemble PMF, since no constraints were applied to such sources. Third, using COPREM with some knowledge on the possible number of sources could also serve to limit the number of PMF sources, especially as PMF tends to find more sources, than what is actually present in order to provide the best fit.

PMF in return can be used to validate existing COPREM profile knowledge. The general agreement between PMF and COPREM solutions increases the confidence in apportionment results, especially with our limited 2-year data set of weekly samples. Meanwhile, as the solutions of COPREM and PMF are not always comparable, which is presumably due to the set constraints of COPREM, certain species can be apportioned very differently such as $\mathrm{Cr}$ (of Soil source) and $\mathrm{Na}$ (of Marine source) (Table S1a).

Current data evaluated by PMF and COPREM failed to apportion biomass combustion, which is an important source where $\mathrm{K}$ and the sugar anhydride levoglucosan are typically chosen as markers. $\mathrm{K}$ is almost evenly distributed among the sources with no clear dominating source and the approximately $10 \%$ difference between PMF and COPREM in the apportionment of $\mathrm{K}$ to $\mathrm{Cu} / \mathrm{Ni}$ is probably a consequence of $\mathrm{K}$ being constrained in the Soil source profile (Table S1). In a previous study at the Canadian Arctic site Alert, $\mathrm{K}$ was apportioned to Marine, Biogenic, Anthropogenic and Photochemistry influenced sources in comparable abundances but 

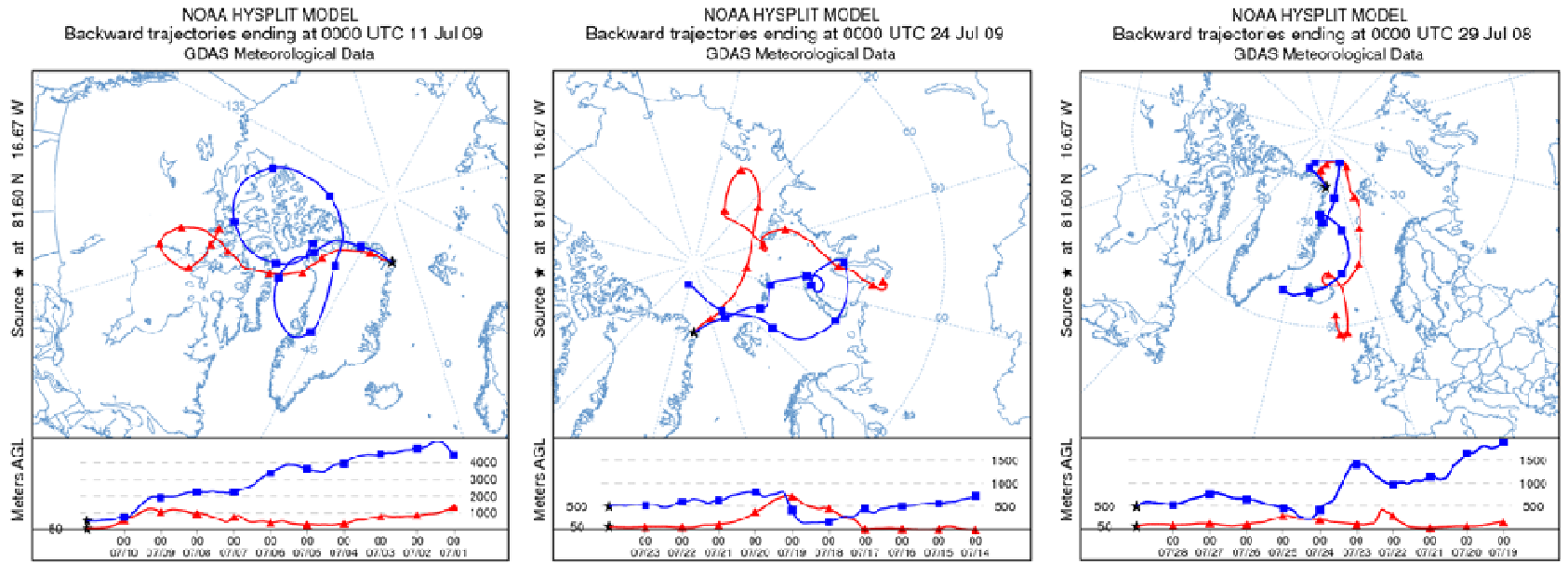

Fig. 7. Air mass back trajectories were calculated for arrival at $50 \mathrm{~m}$ and $500 \mathrm{~m}$ a.s.1. every $24 \mathrm{~h}$ during summer for the period $3 / 2008-2 / 2012$ using the model HYSPLIT. The trajectories below are examples shown for three typical cases: (left) West of Station North (Canadian Arctic, North America and West Greenland); (middle) The North Pole and Siberia and (right) south of Station North (North Atlantic over Greenland).

not apportioned to Soil . (Xie et al., 1999). At Station Nord, $\mathrm{K}$ has previously been apportioned to mainly Soil and $\mathrm{Ma}$ rine and to a minor extent to the copper smelters but not to Combustion (Heidam et al., 2004). $\mathrm{K}$ is a well-known qualitative tracer for biomass burning (Cachier et al., 1995; Lewis et al., 1988), however other sources also contribute to $\mathrm{K}$ in the Arctic environment, mainly earth dust (Frossard et al., 2011).

\section{Conclusions}

In this work, two different source apportionment models were used to explain the chemical observations at Station Nord, Northern Greenland during a two-year period from March 2008 to February 2010. PMF and COPREM produced highly comparable solutions with similar source profiles and source time series. Differences in abundance of particular compounds are evident in particular sources as a consequence of the constraints on the natural sources (Marine and Soil) in COPREM. In addition to the natural sources, we identified three anthropogenic sources which are all highly influenced by metal industries. $\mathrm{Cu} / \mathrm{Ni}$ and $\mathrm{Combus}$ tion sources are subjected to influences from the $\mathrm{Cu}$ and $\mathrm{Ni}$ industry which is most likely of Siberian origin. As expected, the majority of BC originated from these sources (80-98\%). A third source, $\mathrm{Zn}$ source, was only influenced by $\mathrm{Cu}$ to a minor extent and explained a significant fraction of $\mathrm{Zn}$, which could not be apportioned to the other anthropogenic sources. HYSPLIT back trajectories indicated that this source is probably influenced by the Canadian Arctic, though Southern and even Eastern air mass origin also exerted influence on this source. Br is mainly apportioned to Siberian sources though it is most likely sulphuric acid from these sources that acts as transport containers for $\mathrm{Br}$ species, which themselves have local/marine origin.

\section{Supplementary material related to this article is available online at: http://www.atmos-chem-phys.net/13/ 35/2013/acp-13-35-2013-supplement.pdf.}

Acknowledgements. This work was partly financially supported by the Danish Environmental Protection Agency with means from the MIKA/DANCEA funds for Environmental Support to the Arctic Region, which is part of the Danish contribution to "Arctic Monitoring and Assessment Program" (AMAP) and to the Danish research project "Short lived Climate Forcers" (SLCF). The findings and conclusions presented here do not necessarily reflect the views of the Agency. The Royal Danish Airforce is gratefully acknowledged for providing free transport to Station Nord and the authors wish in particular to thank the staff at Station Nord for an excellent and unwavering support. The authors gratefully acknowledge Peter Wåhlin for quality assurance of the analytical measurements.

Edited by: A. Stohl

\section{References}

ACIA: (Arctic Climate Impact Assessment) Overview Report, Cambridge University Press, Cambridge, 140 pp., 2004.

AMAP: The Impact of Black Carbon on Arctic Climate, edited by: Quinn, P. K., Stohl, A., Arneth, A., Berntsen, T., Burkhart, J. F., Christensen, J., Flanner, M., Kupiainen, K., Lihavainen, H., Shepherd, M., Shevchenko, V., Skov, H., and Vestreng, V., Arctic Monitoring and Assessment Programme (AMAP), Oslo, 72 pp., 2011. 
AMAP: (Arctic Monitoring and Assessment Programme) Arctic Pollution Issues: A State of the Arctic Environment Report, Oslo, Norway, 188 pp., 1997.

Baltensperger, U. and Prévôt, A. S. H.: Chemical analysis of atmospheric aerosols, Anal. Bioanal. Chem., 390, 277-280, doi:10.1007/s00216-007-1687-z, 2008.

Barrie, L. A.: Arctic Air-Pollution - an Overview of Current Knowledge, Atmos. Environ., 20, 643-663, 1986.

Barrie, L. A., Hoff, R. M., and Daggupaty, S. M.: The Influence of Mid-Latitudinal Pollution Sources on Haze in the Canadian Arctic, Atmos. Environ., 15, 1407-1419, 1981.

Bourgeois, Q. and Bey, I.: Pollution transport efficiency toward the Arctic: Sensitivity to aerosol scavenging and source regions, J. Geophys. Res., 116, D08213, doi:10.1029/2010jd015096, 2011.

Cachier, H., Liousse, C., Buatmenard, P., and Gaudichet, A.: Particulate Content of Savanna Fire Emissions, J. Atmos. Chem., 22, 123-148, 1995.

Carlson, T. N.: Speculations on the Movement of Polluted Air to the Arctic, Atmos. Environ., 15, 1473-1477, 1981.

Christensen, J. H.: The Danish Eulerian hemispheric model - A three-dimensional air pollution model used for the Arctic, Atmos. Environ., 31, 4169-4191, 1997.

Domine, F., Sparapani, R., Ianniello, A., and Beine, H. J.: The origin of sea salt in snow on Arctic sea ice and in coastal regions, Atmos. Chem. Phys., 4, 2259-2271, doi:10.5194/acp-4-2259-2004, 2004.

Eberly, S.: EPA PMF 1.1 user's guide. U.S. Environmental Protection Agency (EPA), National Exposure Research Laboratory, Research Triangle Park, NC, June, 2005.

Eckhardt, S., Stohl, A., Beirle, S., Spichtinger, N., James, P., Forster, C., Junker, C., Wagner, T., Platt, U., and Jennings, S. G.: The North Atlantic Oscillation controls air pollution transport to the Arctic, Atmos. Chem. Phys., 3, 1769-1778, doi:10.5194/acp-31769-2003, 2003.

Eldering, A. and Cass, G. R.: Source-oriented model for air pollutant effects on visibility, J. Geophys. Res.-Atmos., 101, 1934319369, 1996.

Fenger, M., Sørensen, L. L., Kristensen, K., Jensen, B., Nquyen, Q. T., Nøjgaard, J. K., Massling, A., Skov, H., and Glasius, M.: Sources of anions in aerosols in northeast Greenland during late winter, Atmos. Chem. Phys. Discuss., 12, 14813-14836, doi:10.5194/acpd-12-14813-2012, 2012.

Finlayson-Pitts, B. J. and Hemminger, J. C.: Physical chemistry of airborne sea salt particles and their components, J. Phys. Chem. A, 104, 11463-11477, doi:10.1021/Jp002968n, 2000.

Flanner, M. G., Zender, C. S., Randerson, J. T., and Rasch, P. J.: Present-day climate forcing and response from black carbon in snow, J. Geophys. Res.-Atmos., 112, D11202, doi:10.1029/2006jd008003, 2007.

Flanner, M. G., Zender, C. S., Hess, P. G., Mahowald, N. M., Painter, T. H., Ramanathan, V., and Rasch, P. J.: Springtime warming and reduced snow cover from carbonaceous particles, Atmos. Chem. Phys. Discuss., 8, 19819-19859, doi:10.5194/acpd-8-19819-2008, 2008.

Flyger, H., Heidam, N. Z., Hansen, K. A., Rasmussen, L., and Megaw, W. J.: Background Levels of the Summer Tropospheric Aerosol and Trace Gases in Greenland, J. Aerosol. Sci., 11, 95$110,1980$.
Frossard, A. A., Shaw, P. M., Russell, L. M., Kroll, J. H., Canagaratna, M. R., Worsnop, D. R., Quinn, P. K., and Bates, T. S.: Springtime Arctic haze contributions of submicron organic particles from European and Asian combustion sources, J. Geophys. Res., 116, D05205, doi:10.1029/2010jd015178, 2011.

Garrett, T. J. and Zhao, C. F.: Increased Arctic cloud longwave emissivity associated with pollution from mid-latitudes, Nature, 440, 787-789, doi:10.1038/Nature04636, 2006.

Gautier, D. L., Bird, K. J., Charpentier, R. R., Grantz, A., Houseknecht, D. W., Klett, T. R., Moore, T. E., Pitman, J. K., Schenk, C. J., Schuenemeyer, J. H., Sorensen, K., Tennyson, M. E., Valin, Z. C., and Wandrey, C. J.: Assessment of Undiscovered Oil and Gas in the Arctic, Science, 324, 1175-1179, doi:10.1126/science.1169467, 2009.

Gribble, G. J.: The natural production of organobromine compounds, Environ. Sci. Pollut. R, 7, 37-49, 2000.

Hansen, J. and Nazarenko, L.: Soot climate forcing via snow and ice albedos, P. Natl. Acad. Sci. USA, 101, 423-428, doi:10.1073/pnas.2237157100, 2004.

Heidam, N. Z., Wahlin, P., and Christensen, J. H.: Tropospheric gases and aerosols in northeast Greenland, J. Atmos. Sci., 56, 261-278, 1999.

Heidam, N. Z., Christensen, J., Wahlin, P., and Skov, H.: Arctic atmospheric contaminants in NE Greenland: levels, variations, origins, transport, transformations and trends 1990-2001, Sci. Total Environ., 331, 5-28, doi:10.1016/j.scitotenv.2004.03.033, 2004.

Hirdman, D., Sodemann, H., Eckhardt, S., Burkhart, J. F., Jefferson, A., Mefford, T., Quinn, P. K., Sharma, S., Ström, J., and Stohl, A.: Source identification of short-lived air pollutants in the Arctic using statistical analysis of measurement data and particle dispersion model output, Atmos. Chem. Phys., 10, 669-693, doi:10.5194/acp-10-669-2010, 2010.

Hopke, P. K.: Recent developments in receptor modeling, J. Chemometr., 17, 255-265, doi:10.1002/Cem.796, 2003.

Impey, G. A., Shepson, P. B., Hastie, D. R., Barrie, L. A., and Anlauf, K. G.: Measurements of photolyzable chlorine and bromine during the Polar sunrise experiment 1995, J. Geophys. Res.Atmos., 102, 16005-16010, 1997.

Impey, G. A., Mihele, C. M., Anlauf, K. G., Barrie, L. A., Hastie, D. R., and Shepson, P. B.: Measurements of Photolyzable Halogen Compounds and Bromine Radicals During the Polar Sunrise Experiment 1997, J. Atmos. Chem., 34, 21-37, doi:10.1023/a:1006264912394, 1999.

IPCC: Summary for Policymakers, in: Climate Change 2007: The Physical Science Basis. Contribution of Working Group I to the Fourth Assessment Report of the Intergovernmental Panel on Climate Change, edited by: Solomon, S., Qin, D., Manning, M., Chen, Z., Marquis, M., Averyt, K. B., Tignor, M., and Miller, H. L., Cambridge University Press, Cambridge, United Kingdom, New York, NY, USA, 2007.

Iversen, T.: On the Atmospheric Transport of Pollution to the Arctic, Geophys. Res. Lett., 11, 457-460, 1984.

Kaye, G. W. C. and Laby, T. H.: Tables of physical and chemical constants and some mathematical functions, 12th edn., Longmans, London, New York, viii, 231 pp., 1959.

Klonecki, A., Hess, P., Emmons, L., Smith, L., Orlando, J., and Blake, D.: Seasonal changes in the transport of pollutants into the Arctic troposphere-model study, J. Geophys. Res.-Atmos., 108, 8367, doi:10.1029/2002JD002199, 2003. 
Lewis, C. W., Baumgardner, R. E., Stevens, R. K., Claxton, L. D., and Lewtas, J.: Contribution of Woodsmoke and Motor-Vehicle Emissions to Ambient Aerosol Mutagenicity, Environ. Sci. Technol., 22, 968-971, 1988.

Li, S. M. and Barrie, L. A.: Biogenic Sulfur Aerosol in the Arctic Troposphere .1. Contributions to Total Sulfate, J. Geophys. Res.Atmos., 98, 20613-20622, 1993.

Li, C. and Cornett, J.: Increased zinc concentrations in the Canadian Arctic air, Atmospheric Pollution Research, 2, 45-48, 2011.

Maenhaut, W. and Cornille, P.: Trace-Element Composition and Origin of the Atmospheric Aerosol in the Norwegian Arctic, Atmos. Environ., 23, 2551-2569, 1989.

Mcconnell, J. C., Henderson, G. S., Barrie, L., Bottenheim, J., Niki, H., Langford, C. H., and Templeton, E. M. J.: Photochemical Bromine Production Implicated in Arctic Boundary-Layer Ozone Depletion, Nature, 355, 150-152, 1992.

Morawska, L. and Zhang, J. F.: Combustion sources of particles. 1. Health relevance and source signatures, Chemosphere, 49, 10451058, 2002.

Napari, I., Kulmala, M., and Vehkamaki, H.: Ternary nucleation of inorganic acids, ammonia, and water, J. Chem. Phys., 117, 84188425, doi:10.1063/1.1511722, 2002.

Odemark, K., Dalsoren, S. B., Samset, B. H., Berntsen, T. K., Fuglestvedt, J. S., and Myhre, G.: Short-lived climate forcers from current shipping and petroleum activities in the Arctic, Atmos. Chem. Phys., 12, 1979-1993, doi:10.5194/acp-12-1979-2012, 2012.

Pacyna, J. M., Vitols, V., and Hanssen, J. E.: Size-Differentiated Composition of the Arctic Aerosol at Ny-Alesund, Spitsbergen, Atmos. Environ., 18, 2447-2459, 1984.

Possanzini, M., Buttini, P., and Dipalo, V.: Characterization of a Rural Area in Terms of Dry and Wet Deposition, Sci. Total Environ., 74, 111-120, doi:10.1016/0048-9697(88)90132-5, 1988.

Paatero, P.: Least squares formulation of robust non-negative factor analysis, Chemometr. Intell. Lab., 37, 23-35, 1997.

Quinn, P. K., Miller, T. L., Bates, T. S., Ogren, J. A., Andrews, E., and Shaw, G. E.: A 3-year record of simultaneously measured aerosol chemical and optical properties at Barrow, Alaska, J. Geophys. Res.-Atmos., 107, 4130, doi:10.1029/2001jd001248, 2002.

Quinn, P. K., Shaw, G., Andrews, E., Dutton, E. G., RuohoAirola, T., and Gong, S. L.: Arctic haze: current trends and knowledge gaps, Tellus B, 59, 99-114, doi:10.1111/j.16000889.2006.00238.x, 2007.

Quinn, P. K., Bates, T. S., Baum, E., Doubleday, N., Fiore, A. M., Flanner, M., Fridlind, A., Garrett, T. J., Koch, D., Menon, S., Shindell, D., Stohl, A., and Warren, S. G.: Short-lived pollutants in the Arctic: their climate impact and possible mitigation strategies, Atmos. Chem. Phys., 8, 1723-1735, doi:10.5194/acp8-1723-2008, 2008.

Sander, R. and Bottenheim, J.: A compilation of tropospheric measurements of gas-phase and aerosol chemistry in polar regions, Earth Syst. Sci. Data Discuss., 5, 585-705, doi:10.5194/essdd-5585-2012, 2012.

Schauer, J. J., Rogge, W. F., Hildemann, L. M., Mazurek, M. A., and Cass, G. R.: Source apportionment of airborne particulate matter using organic compounds as tracers, Atmos. Environ., 30, 3837-3855, 1996.
Shindell, D. T., Chin, M., Dentener, F., Doherty, R. M., Faluvegi, G., Fiore, A. M., Hess, P., Koch, D. M., MacKenzie, I. A., Sanderson, M. G., Schultz, M. G., Schulz, M., Stevenson, D. S., Teich, H., Textor, C., Wild, O., Bergmann, D. J., Bey, I., Bian, H., Cuvelier, C., Duncan, B. N., Folberth, G., Horowitz, L. W., Jonson, J., Kaminski, J. W., Marmer, E., Park, R., Pringle, K. J., Schroeder, S., Szopa, S., Takemura, T., Zeng, G., Keating, T. J., and Zuber, A.: A multi-model assessment of pollution transport to the Arctic, Atmos. Chem. Phys., 8, 5353-5372, doi:10.5194/acp-85353-2008, 2008.

Sholkovitz, E. R., Sedwick, P. N., and Church, T. M.: Influence of anthropogenic combustion emissions on the deposition of soluble aerosol iron to the ocean: Empirical estimates for island sites in the North Atlantic, Geochim. Cosmochim. Ac., 73, 3981-4003, doi:10.1016/j.gca.2009.04.029, 2009.

Simpson, W. R., von Glasow, R., Riedel, K., Anderson, P., Ariya, P., Bottenheim, J., Burrows, J., Carpenter, L. J., Frieß, U., Goodsite, M. E., Heard, D., Hutterli, M., Jacobi, H.-W., Kaleschke, L., Neff, B., Plane, J., Platt, U., Richter, A., Roscoe, H., Sander, R., Shepson, P., Sodeau, J., Steffen, A., Wagner, T., and Wolff, E.: Halogens and their role in polar boundary-layer ozone depletion, Atmos. Chem. Phys., 7, 4375-4418, doi:10.5194/acp-74375-2007, 2007.

Skov, H., Christensen, J. H., Goodsite, M. E., Heidam, N. Z., Jensen, B., Wahlin, P., and Geernaert, G.: Fate of elemental mercury in the arctic during atmospheric mercury depletion episodes and the load of atmospheric mercury to the arctic, Environ. Sci. Technol., 38, 2373-2382, doi:10.1021/Es030080h, 2004.

Skov, H., Wahlin, P., Christensen, J., Heidam, N. Z., and Petersen, D.: Measurements of elements, sulphate and $\mathrm{SO}_{2}$ in Nuuk Greenland, Atmos. Environ., 40, 4775-4781, doi:10.1016/j.atmosenv.2006.03.057, 2006.

Song, C. H. and Carmichael, G. R.: The aging process of naturally emitted aerosol (sea-salt and mineral aerosol) during long range transport, Atmos. Environ., 33, 2203-2218, doi:10.1016/S13522310(98)00301-X, 1999.

Stohl, A.: Characteristics of atmospheric transport into the Arctic troposphere, J. Geophys. Res.-Atmos., 111, D11306, doi:10.1029/2005jd006888, 2006.

Sumner, A. L. and Shepson, P. B.: Snowpack production of formaldehyde and its effect on the Arctic troposphere, Nature, 398, 230-233, 1999.

Sverdrup, H. U., Johnson, M. W., and Fleming, R. H.: The oceans, their physics, chemistry, and general biology, Prentice-Hall, inc., New York, x p., 1 1., 1087 p. incl. illus., tables, diagrs. charts (part fold.) 1942.

Viana, M., Kuhlbusch, T. A. J., Querol, X., Alastuey, A., Harrison, R. M., Hopke, P. K., Winiwarter, W., Vallius, A., Szidat, S., Prevot, A. S. H., Hueglin, C., Bloemen, H., Wahlin, P., Vecchi, R., Miranda, A. I., Kasper-Giebl, A., Maenhaut, W., and Hitzenberger, R.: Source apportionment of particulate matter in Europe: A review of methods and results, J. Aerosol Sci., 39, 827-849, doi:10.1016/j.jaerosci.2008.05.007, 2008.

Wang, D. and Sañudo Wilhelmy, S. A.: Vanadium speciation and cycling in coastal waters, Mar. Chem., 117, 52-58, doi:10.1016/j.marchem.2009.06.001, 2009.

Wang, Q., Jacob, D. J., Fisher, J. A., Mao, J., Leibensperger, E. M., Carouge, C. C., Le Sager, P., Kondo, Y., Jimenez, J. L., Cubison, M. J., and Doherty, S. J.: Sources of carbonaceous aerosols 
and deposited black carbon in the Arctic in winter-spring: implications for radiative forcing, Atmos. Chem. Phys., 11, 1245312473, doi:10.5194/acp-11-12453-2011, 2011.

Wåhlin, P.: COPREM - A multivariate receptor model with a physical approach, Atmos. Environ., 37, 4861-4867, doi:10.1016/j.atmosenv.2003.08.032, 2003.
Xie, Y. L., Hopke, P. K., Paatero, P., Barrie, L. A., and Li, S. M.: Identification of source nature and seasonal variations of arctic aerosol by positive matrix factorization, J. Atmos. Sci., 56, 249 $260,1999$. 